\title{
Analisis Unsur Kondisi Fisik Pemain Sepak Bola Mataram Soccer Akademi NTB
}

\author{
Arif Yanuar Musrifin ${ }^{1}$, Andi Anshari Bausad ${ }^{2}$ \\ Program Studi Pendidikan Olahraga dan Kesehatan, Fakultas Ilmu Keolahragaaan dan Kesehatan \\ Masyarakat dan, Universitas Pendidikan Mandalika \\ Alamat e-mail, ayanuarmusrifin@yahoo.com
}

\begin{abstract}
Abstrak. Penelitian ini dilatar belakangi oleh evaluasi managemet dan pelatih club sepak bola Mataram Soccer Akademi NTB Tahun 2019, guna melihat sejauh mana kualitas fisik pemain, khususnya kelompok Usia umur 14 tahun. Pengukuran unsur kondisi fisik pemain dilaksanakan secara rutin sesuai dengan program latihan yang disusun oleh pelatih. Penelitian ini dilakukan dengan tujuan untuk mengetahui kondisi fisik dominan pemain sepak bola Mataram Soccer Akademi NTB Tahun 2019 pada kelompok umur 14 tahun. Rancangan penelitian ini termasuk penelitian deskriptif dengan pendekatan kualitatif. Metode yang digunakan ialah survey dengan teknik pengumpulan data menggunakan tes dan pengukuran. Populasi penelitian ini adalah semua pemain Mataram Soccer Akademi NTB kelompok umur 14 Tahun, dengan jumlah subyek penelitian 20 pemain atau menggunakan teknik studi populasi. Teknik analisis data yang digunakan adalah teknik analisis data statistic deskriptif yaitu teknik mengelompokan data kedalam lima kategori norma tes kondisi fisik kemudian data yang telah dikelompokan dalam kategori kriteria kemampuan dasar sepak bola dihitung persentase kondisi fisik pemain sepak bola. Kesimpulan Penelitian ini bahwa kondisi fisik pemain sepak bola Mataram Soccer Akademi NTB kelompok umur 14 Tahun pada tahun 2019 untuk unsur kondisi fisik Vo 2 Max dalam kategori sedang, kecepatan lari kategori sedang, kelincahan dalam kategori baik dan kemampuan power otot tungkai dalam kategori sedang.
\end{abstract}

Kata Kunci: Analisis, Kondisi Fisik, Sepak Bola.

\section{PENDAHULUAN}

Salah satu unsur atau faktor penting untuk meraih suatu prestasi dalam olahraga, disamping penguasaan teknik, taktik, dan kemampuan mental adalah kondisi fisik. Seberapa besar penting dan pengaruhnya terhadap pencapaian suatu pencapaian suatu prestasi olahraga sangat tergantung kepada kebutuhan atau tuntunan setiap cabang olahraga.

Kondisi fisik adalah satu kesatuan utuh dari komponen-komponen yang tidak dapat dipisahkan begitu saja, baik peningkatan maupun pemeliharaanya. Artinya bahwa di dalam usaha peningkatan kondisi fisik maka seluruh komponen tersebut harus dikembangkan, walaupun disana sini dilakukan dengan sistem prioritas sesuai keadaan atau status tiap komponen itu dan untuk keperluan apa keadaan atau status yang dibutuhkan tersebut.

Kondisi fisik merupakan salah satu unsur yang tak kalah penting dan menjadi dasar dalam mengembangkan teknik, taktik, maupun strategi dalam bermain sepak bola. Kemampuan fisik merupakan kemampuan memfungsikan organ-organ tubuh dalam melakukan aktivitas fisik. Kemampuan fisik sangat penting untuk mendukung mengembangkan aktifitas psikomotor. Gerakan yang terampil dapat dilakukan apabila kemampuan fisiknya memadai. Menurut Mochamad Sajoto (1999: 8), kondisi fisik adalah satu kesatuan utuh dari komponen-komponen yang tidak dapat dipisahkan begitu saja, baik peningkatan maupun pemeliharaan. Artinya bahwa di dalam usaha peningkatan kondisi fisik maka seluruh komponen tersebut harus berkembang.

Menurut dua pengertian mengenai kondisi fisik di atas dapat ditarik kesimpulan bahwa kondisi fisik adalah kemampuan seseorang untuk memfungsikan organ-organ tubuh dalam melakukan segala aktivitas fisik dan merupakan satu kesatuan utuh dari komponen- komponen yang tidak bisa dipisahkan begitu saja baik peningkatan maupun pemeliharaannya. Menurut dua pengertian 
mengenai kondisi fisik di atas dapat ditarik kesimpulan bahwa kondisi fisik adalah kemampuan seseorang untuk memfungsikan organ-organ tubuh dalam melakukan segala aktivitas fisik dan merupakan satu kesatuan utuh dari komponen- komponen yang tidak bisa dipisahkan begitu saja baik peningkatan maupun pemeliharaannya.

Sepak bola menurut Sucipto dkk (2000: 7), adalah permainan beregu, masing-masing regu terdiri dari sebelas pemain, dan salah satunya penjaga gawang. Sedangkan menurut Muhajir (2007: 22) sepak bola adalah suatu permainan yang dilakukan dengan jalan menyepak, yang mempunyai tujuan untuk memasukkan bola ke gawang lawan dengan mempertahankan gawang tersebut agar tidak kemasukan bola”. Sehingga permainan sepak bola merupakan permainan yang dilaksanakan selain mengandalkan tehnik individu, juga merupakan permainan yang lebih mengandalkan keutuhan sebuah tim yang baik.

Mataram soccer academy merupakan salah satu pusat pembinaan atlet sepak bola dalam kelompok umur yang dimulai dari kelompok umur 9 sampai dengan 16 tahun. Academy ini di dirikan di kota mataram, dengan fasilitas stadion gelora 17 desember sebagai tempat latihan. Secara rutin tim pelatih melaksanakan pengukuran tes kondisi fisik, paling tidak dalam satu tahun dilaksanakan sebanyak 2 sampai 3 kali. Pada tahun 2019, khususnya yang menjadi perhatian adalah pada kelompok umur 14 tahun, dimana dalam keikutsertaan dalam 2 event turnamen mengalami penurunan prestasi. Salah satu yang menjadi tolak ukur akhirnya adalah status atau kualitas kondisi fisik pemain.

Pengukuran yang dilakukan meliputi 4 aspek kondisi fisik, yang pertama adalah tes kemampuan kapasitas paru atau VO2 Max yang merupakan volume maksimal $\mathrm{O} 2$ yang diproses oleh tubuh manusia pada saat melakukan kegiatan yang intensif. Kedua, tes kecepatan yaitu kemampuan untuk melakukan gerakangerakan yang sejenis secara berturut-turut dalam waktu yang sesingkat-singkatnya atau kemampuan untuk menempuh suatu jarak yang sesingkat-singkatnya. Ketiga, tes kelincahan adalah kemampuan untuk memgubah posisi dan arah tubuh dengan cepat secara tepat waktu ketika sedang bergerak tanpa kehilangan keseimbangan maupun kesadaran akan €posisi tubuhnya. Keempat, tes power otot tungkai adalah kemampuan dari otot untuk dapat mengatasi tahanan atau beban dalam menjalankan aktifitas. Power otot tungkai merupakan Salah satu faktor yang berperan dalam pencapain tendangan.

Berdasarkan hal diatas jelas kondisi fisik sangat dibutuhkan dalam suatu permainan sepak bola, maka dari itu kondisi fisik pemain harus dilatih agar dapat mencapai prestasi yang tinggi. Berdasarkan latar belakang permasalahan di atas, maka tampaklah permasalahan yang akan di teliti bahwa untuk mencapai prestasi yang tinggi dalam olahraga sepak bola tingkat kondisi fisik diduga sangat mempengaruhi aktifitas bermain sepak bola, namun hal itu belum terbukti secara ilmiah. Oleh sebab itu peneliti tertarik untuk mengetahui tingkat kemampuan kondisi fisik pemain sepak bola Mataram Soccer Academy NTB kelompok umur 14 tahun pada tahun 2019 melalui penelitian secara ilmiah.

\section{METODE PENELITIAN}

Penelitian ini merupakan rancangan penelitian deskriptif dengan pendekatan kualitatif. Penelitian deskriptif yaitu penelitian yang dilakukan untuk menjawab persoalanpersoalan tentang keadaan atau kondisi sebagai mana adanya dilapangan dalam fenomena yang akan diteliti dengan menggambarkan dan melakukan pengamatan terhadap subjek atau variabel yang diteliti dan tidak melakukan pengujian hipotesis (Arikunto, 2013)

Penelitian ini adalah studi populasi yaitu seluruh pemain sepak bola mataram soccer academy kelompok umur 14 tahun yang berjumlah 20 orang.

Instrument yang digunakan dalam penelitian ini dijelaskan sebagai berikut :

\section{1. $\mathrm{VO}_{2} \mathrm{Max}$}

Untuk mengukur $\mathrm{VO}_{2} \mathrm{Max}$ menggunakan BleepTest digunakan untuk mengukur kondisi jantung, paru dan pembuluh darah atau dengan kata lain Cardiovascular. Ketika seseorang memiliki Cardiovascular yang baik dan kuat maka kebugaran dapat dikatakan kuat pula. (Kemenegpora, 2015) 
2. Kecepatan (Tes lari 30 meter)

Testi diberikan kesempatan dua kali kesempatan. Pelari melakukan tes berikutnya setelah berselang minimal satu pelari. Kecepatan lari terbaik yang dihitung. Pencatat waktu dilakukan sampai dengan persepuluh detik $(0,1$ detik), bila memungkinkan dicatat sampai dengan perseratus detik. (Kemenegpora, 2015)

3. Kelincahan (Tes Suttle run)

Testi diberi kesempatan melakukan tes selama satu kali, waktu yang digunakan untuk menempuh tes ini dari start sampai finish. Catatan waktu yang dihitung sampai persepuluh detik $(0,1$ detik) atau perseratus detik $(0,01$ detik). (Kemenegpora, 2015)

4. Power Otot Tungkai (Standing Broad Jump)

Tes yang digunakan pada penelitian ini adalah Standing Broad Jump. Standing Broad Jump merupakan tes untuk mengetahui kemampuan power otot tungkai. Standing Broad Jump merupakan tes yang digunakan mengetahui power otot tungkai dengan melompat kedepan seperti lompat jauh tanpa awalan dan satuan centimeter. (Kemenegpora, 2015)

Teknik analisis data yang digunakan adalah statistik deskriptif yaitu untuk mengumpulkan data, menyajikan data dan menentukan nilai. Setelah diketahui kondisi fisik pemain sepak bola mataram soccer academy, akan dimasukkan dalam pengkategorian, yaitu kategori baik sekali, baik, sedang, kurang, kurang sekali, maka akan dapat di tentukan berapa besar persentase. Setelah data dikelompokan dalam kategori, kemudian mencari persentase masing-masing data data dengan mengunakan rumus persentase.Menurut Suharsimi Arikunto, 2013, rumus persentase yang digunakan adalah:

Keterangan:

$$
\mathrm{P}=\frac{F}{N} X 100 \%
$$

$\mathrm{P}=$ persentase yang dicari

$\mathrm{F}=$ frekuensi

$\mathrm{N}=$ jumlah responden

\section{HASIL DAN PEMBAHASAN Hasil Penelitian}

Hasil penelitian disajikan dalam bentuk data pengkategorian dan hasil prosentasenya. Setiap pengukuran kondisi fisik tentunya susuai dengan instrumen penelitian, yang kemudian analisa dan dijelaskan secara detail. Berikut ini adalah penjelasana di setiap pengambilan data yang sudah dilaksanakan.

\section{Tes VO2 Max}

Tabel 1. Hasil Tes Pengukuran Vo2 Max

\begin{tabular}{|c|c|c|c|} 
No & Nama & Hasil & Kategori \\
\hline 1 & M. I & 30.6 & Kurang Sekali \\
\hline 2 & LHK & 33.5 & Kurang \\
\hline 3 & R & 33.7 & Kurang \\
\hline 4 & Z & 45.8 & Baik \\
\hline 5 & H & 46.2 & Baik \\
\hline 6 & A & 45.5 & Baik \\
\hline 7 & O & 33.7 & Kurang \\
\hline 8 & LTH & 29.3 & Kurang Sekali \\
\hline 9 & AN & 44.9 & Baik \\
\hline 10 & JK & 41.8 & Sedang \\
\hline 11 & MN & 51.6 & Baik Sekali \\
\hline 12 & LMA & 40.5 & Sedang \\
\hline 13 & DG & 43.5 & Sedang \\
\hline 14 & HP & 40.5 & Sedang \\
\hline 15 & AAB & 38.5 & Sedang \\
\hline 16 & PMY & 37.5 & Sedang \\
\hline 17 & SS & 42.0 & Sedang \\
\hline 18 & MAAM & 41.1 & Sedang \\
\hline 19 & CK & 43.9 & Baik \\
\hline 20 & DA & 50.2 & Baik Sekali \\
\hline
\end{tabular}

Dari hasil tes VO2 Max pemain sepak bola mataram soccer academy kelopok umur 14 tahun terdapa 2 pemain dengan kategori baik sekali, 5 pemain dengan kategori baik, 8 pemain dengan kategori sedang, 3 pemain dengan kategori kurang dan 2 pemain dengan kategori kurang sekali. Berikut ini adalah hasil perhitungan persentasenya.

Tabel 2. Persentase Hasil

\begin{tabular}{|c|c|c|}
\hline Kategori & Jumlah & Persentase \\
\hline Kurang sekali & 2 & 10 \\
\hline Kurang & 3 & 15 \\
\hline Sedang & 8 & 40 \\
\hline Baik & 5 & 25 \\
\hline Baik sekali & 2 & 10 \\
\hline Total & $\mathbf{2 0}$ & $\mathbf{1 0 0}$ \\
\hline
\end{tabular}

Keterangan:

Tabel diatas data dijelaskan bahwa kondisi fisik dalam hal VO2 Max pemain sepak bola mataram soccer academy kelopok umur 14 tahun. Kategori kurang sekali sebanyak 10\%, kategori kurang sebanyak 15\%, sedang sebanyak $40 \%$. Kategori baik $25 \%$, dan kategori baik sekali sebanyak $10 \%$ sehingga berdasarkan hasil kesimpulan diatas bahwa kemampaun kondisi fisik dalam hal VO2 Max termasuk kategori sedang. 
2. Tes Kecepatan Lari 30 Meter.

Tabel 3. Hasil Tes Kecepatan Lari 30 Meter

\begin{tabular}{|c|c|c|c|} 
No & Nama & Hasil & Kategori \\
\hline 1 & M. I & 5.86 & Kurang Sekali \\
\hline 2 & LHK & 5.9 & Kurang Sekali \\
\hline 3 & R & 4.09 & Baik \\
\hline 4 & Z & 4 & Baik \\
\hline 5 & H & 4 & Baik \\
\hline 6 & A & 4.13 & Baik \\
\hline 7 & O & 5.11 & Kurang \\
\hline 8 & LTH & 4.2 & Baik \\
\hline 9 & AN & 4.28 & Baik \\
\hline 10 & JK & 3.59 & Baik Sekali \\
\hline 11 & MN & 4.06 & Baik \\
\hline 12 & DG & 4.73 & Kurang \\
\hline 13 & HP & 4.2 & Baik \\
\hline 14 & AAB & 4.41 & Sedang \\
\hline 15 & PMY & 4.2 & Baik \\
\hline 16 & SS & 4 & Baik \\
\hline 17 & MAAM & 4.19 & Baik \\
\hline 18 & CK & 4.47 & Sedang \\
\hline 19 & DA & 4.2 & Baik \\
\hline 20 & M. I & 3.58 & Baik Sekali \\
\hline
\end{tabular}

Dari hasil tes kecepatan lari 30 meter pemain sepak bola mataram soccer academy kelopok umur 14 tahun terdapat 2 pemain dengan kategori baik sekali, 12 pemain dengan kategori baik, 2 pemain dengan kategori sedang, 2 pemain dengan kategori kurang dan 2 pemain dengan kategori kurang sekali. Berikut ini adalah hasil perhitungan persentasenya.

Tabel 4. Persentase Hasil

\begin{tabular}{|c|c|c|}
\hline Kategori & Jumlah & Persentase \\
\hline Kurang sekali & 2 & 10 \\
\hline Kurang & 2 & 10 \\
\hline Sedang & 2 & 10 \\
\hline Baik & 12 & 60 \\
\hline Baik sekali & 2 & 10 \\
\hline Jumlah & $\mathbf{2 0}$ & $\mathbf{1 0 0}$ \\
\hline
\end{tabular}

Tabel diatas data dijelaskan bahwa kondisi fisik dalam hal Kecepatan pemain sepak mataram soccer academy kelopok umur 14 tahun. Kategori kurang sekali sebanyak 10\%, kategori kurang sebanyak 10\%, Kategori sedang sebanyak $10 \%$. Kategori baik sebanyak $60 \%$, dan kategori baik sekali sebanyak $10 \%$. Berdasarkan data diatas bahwa kemampuan kondisi fisik pemain sepak mataram soccer academy kelopok umur 14 tahun dalam hal kecepatan termasuk kategori baik.

\section{Tes Kelincahan}

Tabel 5. Hasil Tes Kecepatan Kelincahan

\begin{tabular}{|c|c|c|c|}
\hline No & Nama & Hasil & Kategori \\
\hline 1 & M. I & 16 & kurang sekali \\
\hline 2 & LHK & 16.3 & kurang sekali \\
\hline 3 & R & 14 & kurang \\
\hline 4 & Z & 13.5 & baik \\
\hline 5 & H & 13.45 & baik \\
\hline 6 & A & 12.11 & baik sekali \\
\hline 7 & O & 13.54 & baik \\
\hline 8 & LTH & 15 & kurang \\
\hline 9 & AN & 13.56 & sedang \\
\hline 10 & JK & 14.9 & sedang \\
\hline 11 & MN & 13.54 & sedang \\
\hline 12 & DG & 13.53 & baik \\
\hline 13 & AAB & 14 & kurang \\
\hline 14 & PMY & 14.2 & sedang \\
\hline 15 & SS & 14.3 & sedang \\
\hline 16 & MAAM & 14.3 & sedang \\
\hline 17 & CK & 14.5 & sedang \\
\hline 18 & DA & 15 & kurang \\
\hline 19 & M. I & 14 & sedang \\
\hline 20 & M. I & 12.1 & baik sekali \\
\hline & Dai & kelincan & pemin \\
\hline
\end{tabular}

Dari hasil tes kelincahan pemain sepak bola mataram soccer academy kelopok umur 14 tahun terdapat 2 pemain dengan kategori baik sekali, 4 pemain dengan kategori baik, 8 pemain dengan kategori sedang, 4 pemain dengan kategori kurang dan 2 pemain dengan kategori kurang sekali. Berikut ini adalah hasil perhitungan persentasenya.

Tabel 6. Persentase Hasil

\begin{tabular}{|c|c|c|}
\hline Kategori & Jumlah & Persentase \\
\hline Kurang sekali & 2 & 10 \\
\hline Kurang & 4 & 20 \\
\hline Sedang & 8 & 40 \\
\hline Baik & 4 & 20 \\
\hline Baik sekali & 2 & 10 \\
\hline Total & $\mathbf{2 0}$ & $\mathbf{1 0 0}$ \\
\hline
\end{tabular}

Tabel diatas data dijelaskan bahwa kondisi fisik dalam hal tes kelincahan lari 
shuteel run pemain sepak bola mataram soccer academy kelopok umur 14 tahun. Kategori kurang sekali sebanyak $10 \%$, kategori kurang sebanyak 20\%, kategori sedang sebanyak $40 \%$. Kategori baik sebanyak $20 \%$, dan kategori baik sekali $10 \%$. Berdasarkan hasil data diatas bahwa kemampuan kondisi fisik pemain mataram soccer academy kelopok umur 14 tahun dalam hal kelincahan termasuk kategori sedang.

\section{Power Otot Tungkai (Standing Broad Jump)}

Tabel 7. Hasil Tes Power Otot Tungkai (Standing broad Jump)

\begin{tabular}{|c|c|c|c|}
\hline No & Nama & Hasil & Kategori \\
\hline 1 & M. I & 1.81 & kurang \\
\hline 2 & LHK & 1.51 & kurang sekali \\
\hline 3 & R & 1.89 & kurang \\
\hline 4 & Z & 2.56 & sedang \\
\hline 5 & H & 2.56 & sedang \\
\hline 6 & A & 1.51 & kurang sekali \\
\hline 7 & O & 2.25 & kurang \\
\hline 8 & LTH & 1.82 & kurang \\
\hline 9 & AN & 2.4 & sedang \\
\hline 10 & JK & 2.48 & sedang \\
\hline 11 & MN & 2.76 & baik \\
\hline 12 & DG & 2.4 & sedang \\
\hline 13 & AAB & 2.5 & sedang \\
\hline 14 & SS & 1.82 & kurang \\
\hline 15 & MAAM & 2.64 & baik \\
\hline 16 & CK & 4.12 & sedang \\
\hline 17 & DA & 2.53 & sedang \\
\hline 18 & M. I & 5.12 & baik sekali \\
\hline 19 & M. I & 2.49 & sedang \\
\hline 20 & M. I & 5.11 & baik sekali \\
\hline
\end{tabular}

Dari hasil tes power otot tungkai pemain sepak bola mataram soccer academy kelopok umur 14 tahun terdapat 2 pemain dengan kategori baik sekali, 2 pemain dengan kategori baik, 9 pemain dengan kategori sedang, 5 pemain dengan kategori kurang dan 2 pemain dengan kategori kurang sekali. Berikut ini adalah hasil perhitungan persentasenya.

Tabel 8. Persentase Hasil

\begin{tabular}{|l|c|c|}
\hline Kategori & Jumlah & Persentase \\
\hline Kurang sekali & 2 & 10 \\
\hline Kurang & 5 & 25 \\
\hline
\end{tabular}

\begin{tabular}{|l|c|c|} 
Sedang & 9 & 45 \\
\hline Baik & 2 & 10 \\
\hline Baik sekali & 2 & 10 \\
\hline Total & $\mathbf{2 0}$ & $\mathbf{1 0 0}$ \\
\hline
\end{tabular}

Tabel diatas data di jelaskan bahwa kondisi fisik dalam hal power otot tungkai pemain sepak bola mataram soccer academy kelopok umur 14 tahun. Kategori kurang sekali sebanyak $10 \%$, kategori kurang sebanyak 25\%, kategori sedang $45 \%$. Kategori baik sebanyak 10\%, dan kategori baik sekali sebanyak 10\%. Sehingga berdasarkan hasil data di atas bahwa kemampuan kondisi fisik power otot tungkai pemain termasuk kategori sedang.

\section{Pembahasan}

Hasil pengukuran 4 unsur kondisi fisik yang sudah dilaksanakan akan menjadikan dasar untuk mengevaluasi kinerja management ssb (sekolah sepakbola) sepak bola mataram soccer academy kelopok umur 14 tahun. Apakah ada perubahan program latihan yang sudah dilaksanakan, kualitas pelatih, sarana dan prasarana dan bahkan keseriusan management dalam melaksanakan visi dan misi club.

Hasil tes kemampuan VO2 Max yang sudah dilaksanakan didapat kan rata-rata dalam kategori sedang, seorang atlet sepakbola kemampuan VO2 Max sangat penting keberadaannya. Dimana VO2 Max merupakan unsur kondisi fisik utama yang harus dimiliki oleh atlet sepak bola, dikarenakan tipe dari dari permainan sepak bola yang dilaksanakan 2 x 45 menit membutuhan kemampuan paru maksimal. Denni \& suharjana, 2016. Dalam permainan sepakbola kemampuan, daya tahan aerobicyang baik atau VO2 Max yang tinggi sangat diprioritaskan, apabila para pemain sepak bola dalam kemampuan yang hampir sama, maka kalah atau enang ditentukan oleh kondisi fisik dan mental seorang pemain.

Kemampuan kecepatan dari hasil tes lari kecepatan 30 meter, tunjuan dari tes ini adalah untuk mengukur kecepatan berlari pemain sepak bola, kecepatan berlari berfungsi baik untuk melaksanakan serangan ataupun pola bertahan, seorang pemain sepakbola yang mempunyai kecepatan yang baik maka dapat meguasai permainan. Akan tetapi unsur kondisi fisik kecepatan berlari harus juga diimbangi dengan 
kemampuan mengiring bola dengan baik, dengan kualitas menggiring bola dengan baik, maka harus bisa dilaksanakan dengan berlari yang cukup cepat. Dan unsur kondisi fisik mengiring bola dengan berlari cepat, harus ditopang dengan keseimbangan dan kelentukan yang baik oleh seorang pemain sepakbola. Dari hasil penelitian rata-rata hasil pengukuruan tes kecepatan lari 30 meter pemain sepak bola mataram soccer academy kelopok umur 14 tahun dalam kategori baik.

Hasil tes pengukuran kelincahan, pada pemain sepak bola mataram soccer academy kelopok umur 14 tahun dalam kategori sedang, sehingga perlu ditinggkatnya menjadi kategori baik abahkan sangat baik. Ramadhan, Herita, 2018, kelincahan merupakan salah satu unsur penting dalam dribbling, jika seseorang mempunyai kelincahan yang baik maka dalam keterampilan dribbling pun akan baik dan memudahkan mereka dalam melewati lawan, karena jika dalam dribbling tidak memiliki kelincahan bola akan mudah didapatkan oleh lawan. Pola latihan dengan menggunakan metode Latihan Kelincahan dilakukan

secara bertahap dari mulai gerakan yang mudah sampai dengan gerak yang sulit.

Hasil tes pengukuran power otot tungkai, pada pemain sepak bola mataram soccer academy kelopok umur 14 tahun dalam kategori sedang, sehingga perlu ditinggkatnya menjadi kategori baik bahkan sangat baik. Kegunaaan power otot tungkai dalam permainan sepak bola menurut Haris Satria\& Marja Desandra, 2016. hal melaksanakan tendangan jarak jauh ini dapat digunakan seperti crossing, shooting, tendangan bebas dan tendangan coorner. Power otot tungkai digunakan dalam menunjang kecepatan lari pendek 10 sampai 30 meter dalam lapangan sepak bola, juga dapat menunjang kemampuan melompat dengan cepat atau explosif power ketika akan menyundul bola baik saat bertahan ataupun menyerang.

Dalam kegiatan olahraga, kondisi fisik seseorang akan sangat mempengaruhi bahkan menentukan gerak penampilannya. Menurut Harsono (2001: 4), dengan kondisi fisik yang baik akan berpengaruh terhadap fungsi dan sistem organisme tubuh, diantaranya:
1. Akan
ada
peningkatan
dalam

kemampuan sistem sirkulasi dan kerja jantung.

2. Akan ada peningkatan dalam kekuatan, kelentukan, stamina dan komponen kondisi fisik lainnya

3. Akan ada ekonomi gerak yang lebih baik pada waktu latihan.

4. Akan ada pemulihan yang lebih cepat dalam organ-organ tubuh setelah latihan.

5. Akan ada respon yang cepat dari organisme tubuh kita apabila sewadiperlukan.

6. Apabila kelima keadaan di atas kurang atau tidak tercapai setelah diberi latihan kondisi fisik tertentu, maka hal itu dapat diktu-waktu respon.

\section{KESIMPULAN}

Kesimpulan penelian ini menurut hasil analisi yang sudah dilaksanakan adalah unsur kondisi fisik Vo 2 Max dalam kategori sedang, kecepatan lari kategori sedang, kelincahan dalam kategori baik dan kemampuan Power otot tungkai dalam kategori sedang.

\section{SARAN}

Gagasan selanjutnya dari penelitian ini adalah bagaimana meningkatkan kondisi fisik pemian mataram soccer academy kelopok umur 14 tahun menjadi lebih baik melalui metode atau bentuk latihan yang sesuai dengan kelompok umur nya. Dimana kita ketahui bahwa SSB ini terdapat beberpa kelompok umur mulai dari umur 9 sampai 16 tahun.

\section{UCAPAN TERIMA KASIH}

Ucapan terima kasih disampaikan kepada keluarga besar SSB mataram soccer academy, mulai dari management, pelatih, siswa dan orang tua siswa.

\section{DAFTAR PUSTAKA}

Arikunto.Suharsimi. 2013. Prosedur Penelitian. Jakarta. Rineka Cipta

Denni, Suharjana, 2016. Pengaruh Metode Latihan Dan Vo2 Max Terhadap Dasar Sepak Bola . Jurnal Keolahragaan, Volume 4 - Nomor 2 (164-174). Universitas Negeri Yogyakarta, http://journal.uny.ac.id/index.php/jolahrag a

Harsono. (2001). Latihan Kondisi Fisik. Bandung: Proyek Pengembangan Lembaga Pendidikan Tenaga 
Kependidikan, Departemen Pendidikan dan Budaya.

Haris Satria \& Marja Desandra, 2016. Pengaruh

Latihan Power Otot Tungkai Terhadap

Peningkatan Tendangan Jarak Jauh

Sepakbola. Jurnal Ilmiah Bina Edukasi

Vol.9 No.1, Juni 2016: 11-20.

Kemenegpora, 2015. Panduan Penetapan

Parameter Tes Pada Pusat Pendidikan dan Pelatihan Pelajar dan Sekolah khusus olahragawan.

Muhajir. 2007. Pendidikan Jasmani Olahraga dan Kesehatan. Penerbit Erlangga.Jakarta.

Ramadhan, Herita, 2018. Model Latihan Sepak Bola. Jurnal pendidikan Jasmani dan Olahraga, Volume 17, Nomor 2. JPOK FKIP Universitas Lambung Mangkurat

Sajoto. 1988. Pembinaan Kondisi Fisik Dalam Olahraga. Jakarta: Departemen Pendidikan dan Kebudayaan Direktorat Jenderal Pendidikan Tinggi Proyek Penggembangan Lembaga pendidikan Tenaga Kependidikan.

Sucipto, dkk. 2000. Sepakbola. Departemen Pendidikan Nasional Direktorat Jenderal Pendidikan Dasar dan Menengah Bagian Proyek Penataran Guru SLTP Setara DIII. IKIP Yogyakarta. Yogyakarta 